JURNAL PUBLIPRENEUR: POLITEKNIK NEGERI MEDIA KREATIF

Vol. 8, No. 2, December 2020, hal. 31-44

Submitted: 1 December 2020

Revised: 10 December 2020

Accepted: 20 December 2020

\title{
SEMIOTIC ANALYSIS OF ANIMATED TV SERIES `RIKO: JARAK MATAHARI_BUMI " AS AN EDUCATIONAL MEDIA FOR CHILDREN
}

\author{
Lani Siti Noor Aisyah \\ Politeknik Negeri Media Kreatif \\ E-mail: lani.aisyah@polimedia.ac.id
}

\begin{abstract}
Children are an age group who adapts very well to the stimuli what they receive from their environment, such as movies and games. Unfortunately, entertainment these days contains many negative messages that has an impact on the erosion of moral values, which are, then implemented in the form of negative thought patterns and behaviors.

The purpose of this research is to examine how children's entertainment media can be educational, entertaining, and easy to understand with a case study of the animated to series 'Riko: Jarak Matahari dan Bumi'

This research was studied using the method of pragmatic semiotics initiated by Charles Sanders Peirce by analyzing semiotic elements, then validated with the psychological theory of child development. The results of the analysis show that the semiotic elements presented in "Riko: Jarak Matahari dan Bumi' are in line with the psychological principles of child development.
\end{abstract}

Keyword: semiotics, animated movie, education, chilren's psychological development

\section{ANALISIS SEMIOTIKA FILM ANIMASI ‘RIKO : JARAK BUMI DAN MATAHARI’ SEBAGAI MEDIA EDUKASI BAGI ANAK - ANAK}

\begin{abstract}
ABSTRAK
Anak-anak adalah kelompok usia yang sangat adaptif terhadap stimulus-stimulus yang mereka terima dari lingkungan sekitarnya, contohnya dari film dan games. Sayangnya, saat ini banyak media hiburan yang mengandung konten-konten negatif yang berdampak pada terkikisnya nilai-nilai moral, lalu diimplementasikan dalam bentuk pola pikir dan prilaku negatif.

Tujuan penelitian ini adalah meneliti bagaimana media hiburan anak yang edukatif, menghibur, dan mudah dipahami dengan studi kasus film animasi 'Riko : Jarak Matahari dan Bumi'.

Penelitian ini dikaji dengan metode semiotika pragmatis yang digagas Peirce dengan menganalisa unsur-unsur semiotis, lalu divalidasi dengan teori psikologi perkembangan anak. Hasil analisis menunjukan bahwa unsur-unsur semiotis yang disajikan dalam 'Riko: Jarak Matahari dan Bumi' sangat sesuai dengan kaidah-kaidah psikologi perkembangan anak.

Kata kunci : semiotika, film kartun, edukasi, psikologi perkembangan anak.
\end{abstract}




\section{PENDAHULUAN}

Pada dasawarsa terakhir, tidak dapat dipungkiri bahwa seluruh lapisan masyarakat Indonesia merasakan dampak pesatnya penyebaran dan percepatan arus informasi. Wacana yang disampaikan pun mencakup berbagai aspek kehidupan seperti ekonomi, sosial, politik, budaya dan teknologi. Wacana disampaikan dalam berbagai paradigma didukung perkembangan teknologi informasi melalui media komunikasi digital. Penggunaan platform media sosial seperti Instagram dan Twitter, programprogram televisi, film videogame, virtual reality, augmented reality, film dan musik yang didukung video sharing platform seperti Netflix dan YouTube, seakan sudah melebur dalam rutinitas keseharian masyarakat pengguna internet. Kecenderungan tersebut memunculkan entitas dengan wacananya sendiri. Yang dimaksudkan dengan entitas dan wacana tersebut, dalam konteks penelitian ini adalah kebutuhan masyarakat akan sarana hiburan edukatif yang mudah diakses. Ironisnya, media hiburan digital yang seyogiannya berperan sebagai media edukasi bagi masyarakat justru banyak menyajikan konten-konten kurang bermanfaat dan bahkan bersifat negatif. Seperti gaya hidup hedonis, prank, kekerasan baik verbal maupun non verbal, seks, kriminal dan lainnya. Dampak sosialnya antara lain terkikisnya nilai-nilai moral, yang diimplementasikan dalam bentuk pola pikir dan prilaku negatif masyarakat.

Tak terkecuali bagi masyarakat kelompok usia anak-anak, kontenkonten negatif tersebut bahkan memberi dampak yang lebih berbahaya. Games dan film kartun sebagai contoh media hiburan yang sangat disukai anak-anak, seringkali malah menyampaikan stimulus-stimulus negatif. Informasi yang dituturkan dalam bentuk bahasa verbal (audio) dan bahasa visual, dipersepsikan dengan cepat oleh anak, lalu diekspresikan dalam bentuk konkrit berupa tutur kata dan prilaku. Disebutkan oleh Sit bahwa pada anak usia dini terjadi perkembangan fisik maupun psikis terbaik sepanjang hidup manusia (Sit, 2015, h.4). Menurut White, Osborn dan Bloom, kemampuan kognitif anak pada usia 4 tahun sudah mencapai $40 \%, 80 \%$ ketika berusia 8 tahun, dan 100\% ketika berusia 18 tahun. Diawali dengan tahap sensoris-motoris yakni mengolah informasi melalui panca indera, lalu berlanjut pada tahap pra operasional konkrit yakni proses pemahaman terhadap benda yang diiringi oleh kemampuan imajinasi anak. Dari proses kognitif tersebut, membawa anak pada perkembangan psikis, antara lain kemampuan anak dalam berbahasa, kemampuan emosional, kemampuan berinteraksi dengan lingkungan, pemahaman moral dalam membedakan baik dan buruk, dan memahami konsep agama.

Dari paparan diatas, dapat kita telaah bahwa stimulus-stimulus dari lingkungan sepanjang rentang pertumbuhan anak haruslah stimulusstimulus yang baik. Termasuk stimulus dalam bentuk informasi-infomasi yang disampaikan melalui media-media digital yang ditonton anak sehari-hari. Dapat dibayangkan dampak buruknya terhadap moralitas bangsa jika generasi muda, khususnya anak-anak - 


\section{JURNAL PUBLIPRENEUR: POLITEKNIK NEGERI MEDIA KREATIF Vol. 8, No. 2, December 2020, hal. 31-44}

sepanjang perkembangannya banyak terpapar stimulus-stimulus negatif. Maka menurut penulis studi dan penelitian media edukasi digital secara berkesinambungan perlu untuk dilakukan, merujuk pada pendapat Sobur bahwa film memiliki kekuatan dan kemampuan menjangkau banyak segmen sosial dan mempengaruhi khalayaknya (Sobur, 2016, h.27).

Dari sekian banyak media edukasi digital dengan segmentasi anak-anak, penulis menemukan sebuah film kartun karya sineas Indonesia yang sangat unik berjudul 'Riko the Series'. Pertama kali dirilis pada November tahun 2019 di kanal YouTube berdurasi sekitar 5:30 menit. Keunikan dari serial animasi yang diproduksi oleh Garis Sepuluh Corporation ini terletak pada kompleksitas informasi yang dibangun dari beberapa bidang keilmuan sebagai subjek belajar bagi anak-anak. Subjeksubjek yang menjadi tema film ini yaitu ilmu pengetahuan yang dihubungkan berdasarkan petunjuk Al-Qur'an. Cerita dituturkan melalui bahasa verbal dan bahasa visual yang sederhana berdasarkan kemampuan logika dan emosional anak-anak agar mudah dipahami.

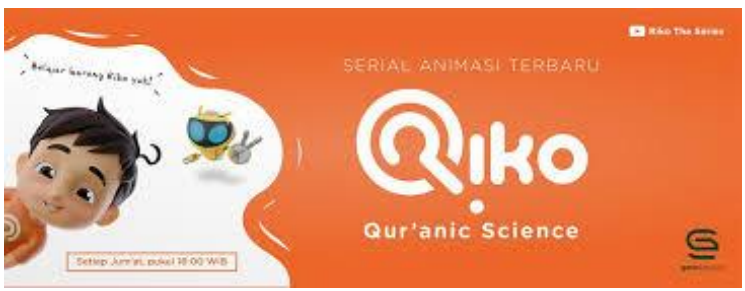

Gambar 1: Riko the Series

Sumber:

https://images.app.goo.gl/EKFFLfY9KrPc6Ayr
Ilmu pengetahuan bukanlah subjek yang mudah untuk disampaikan kepada anak-anak dalam komunikasi satu arah seperti film. Salah satu cara berkomunikasi yang efektif dengan anak-anak untuk menjelaskan sesuatu adalah dengan memberikan contoh konkrit yang disampaikan melalui komunikasi verbal maupun visual.

Dalam penelitian ini, akan dianalisis beberapa adegan (scenes) dalam film animasi Riko yang menganalogikan fenomena-fenomena alam melalui tanda-tanda visual yang mampu dipersepsikan oleh anak-anak sebagai target audiens. Selain itu, pada penelitian ini akan dikupas unsur-unsur semiotis, yaitu proses pemaknaan tanda-tanda visual tersebut berdasarkan perspektif keilmuan Desain Komunikasi Visual.

Karena keterbatasan ruang, maka dipilih studi kasus dari serial animasi Riko, yaitu 1 episode berjudul 'Jarak Matahari dan Bumi'.

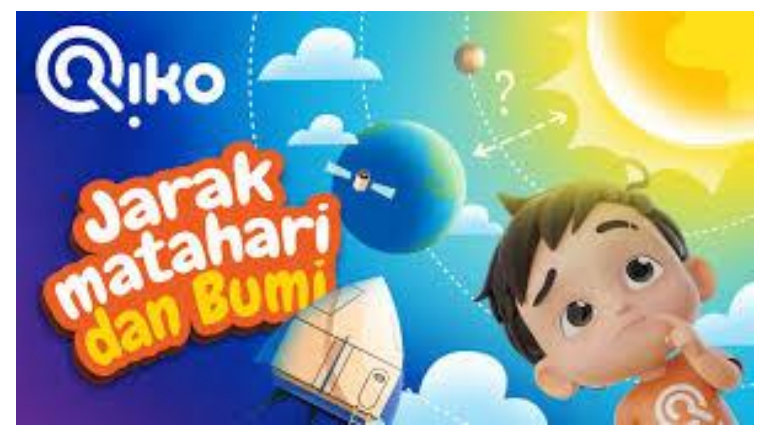

Gambar 2: Riko the Series - episode Jarak Matahari dan Bumi Sumber:

https://www.youtube.com/watch?v=mnYi94h2 $894 \mathcal{E}$ app $=$ desktop

Tema 'jarak matahari dan bumi' adalah subjek yang menarik dan kompleks untuk dipresentasikan melalui 
penggambaran visual, mengingat segmentasi film animasi Riko ini adalah anak-anak.

\section{METODE PENELITIAN}

Tanda-tanda visual dalam film untuk menyampaikan cerita yang mudah dipahami anak-anak, dapat dipresentasikan secara ikonis, indeksikal dan simbolis. Jika berbicara tentang ikon, indeks dan simbol, maka wilayah penelitian yang tepat untuk dipadukan dengan perspektif keilmuan Desain Komunikasi Visual adalah semiotika. Semiotika dianggap sebagai instrumen yang mampu mengupas tanda serta pemaknaannya yang bersintesis dengan dinamika sosial, budaya, sejarah bahkan science dan teknologi. Selaras dengan yang dinyatakan Saidi bahwa film adalah media informasi yang merupakan pusat wacana dalam medan yang luas (Saidi, 2017, h.36). Begitupun dalam serial animasi Riko, subjek kompleks ilmu pengetahuan yang dihubungkan berdasarkan petunjuk Al-Qur'an, selain mudah dipahami tetapi juga harus interpretatif.

Dengan metode analisis semiotika, serial 'Riko the Series' episode 'Jarak Matahari dan Bumi', maka penelitian ini dilakukan secara kualitatif. Adapun data-data penelitian bersumber dari observasi, wawancara dan studi literatur. Observasi dan wawancara dilakukan terhadap anak berusia 6-8 tahun yang sudah menonton serial 'Riko the Series' episode 'Jarak Matahari dan Bumi' dan didampingi orangtuanya. Sedangkan metode semiotika yang digunakan sebagai instrumen adalah teori Semiotika yang digagas Charles
Sanders Pierce.

Peirce merumuskan proses terbentuknya tanda dan pemaknaannya (semiosis) dalam konsep triadik yang berangkat dari logika dalam kejadian sebab-akibat. Dalam semiosis Peirce, objek penelitian ditempatkan sebagai 3 (tiga) unsur yakni representament, interpretant dan object. Maka akan diketahui apakah bahasa visual yang direpresentasikan dalam adeganadegan serial Riko, apakah sebagai icon (keserupaan), index (hubungan kontinuitas) ataukah symbol (makna yang dibentuk atas konvensi sosial).

Icon, index dan symbol akan diketahui melalui formulasi triadik Peirce yang diuraikan Munday dalam Chandler yaitu :

1. Object. Sesuatu yang berada di balik tanda, disebut sebagai 'referent'

2. Representament. Yaitu bentuk yang dipergunakan sebagai tanda namun tidak selalu merujuk pada bentuk material tapi lebih kepada 'signvechile'.

3. Interpretant. Bukan dimaksudkan sebagai interpreter, tapi lebih kepada 'kesan' yang dibuat oleh tanda.

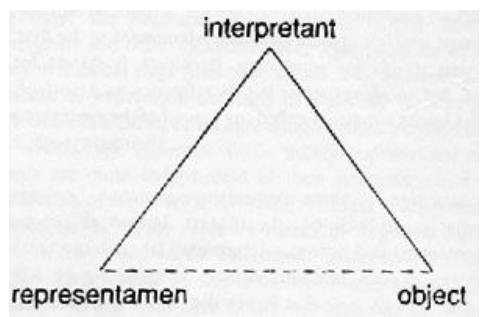

Gambar 3 : Konsep triadik Peirce Sumber: Munday dan Chandler dalam Aisyah, 2018.

Formulasi triadik diatas akan dijadikan 


\section{JURNAL PUBLIPRENEUR: POLITEKNIK NEGERI MEDIA KREATIF Vol. 8, No. 2, December 2020, hal. 31-44}

Submitted: 1 December 2020

Revised: 10 December 2020

Accepted: 20 December 2020

acuan untuk menganalisa struktur visual dari cerita yang disajikan 'Riko the Series : Jarak Matahari dan Bumi' melalui adegan-adegan (scenes) yang menjelaskan bagaimana sebuah tanda dapat memiliki makna, lalu makna tersebut akan bersintesis menjadi tanda baru dengan makna yang terus berkembang.

Analisis akan dipaparkan secara deskriptif berdasarkan studi kasus pada beberapa pembagian plot (sequences) dan pembagian adegan (scene). Mengingat objek penelitian adalah media digital yang diperuntukan bagi tujuan edukasi, maka akan dideskripsikan aspek psikologi (kognitif) anak usia 8 tahun (usia Riko, sang tokoh utama) pada tahap perkembangan konkrit operasional. Tahap konkrit operasional yang dialami tokoh utama lalu diproyeksikan pada proses pemaknaan tanda (semiosis).

\section{HASIL DAN PEMBAHASAN}

Riko the Series menceritakan Riko seorang anak laki-laki berusia 8 tahun dengan karakteristik cerdas, memiliki rasa ingin tahu yang tinggi, kritis, dan kreatif. Ia selalu melontarkan pertanyaan-pertanyaan tentang fenomena-fenomena alam yang ia lihat dan alami, lalu dijawab oleh sahabatnya sebuah robot Q110.

Dalam episode 'Jarak Bumi dan Matahari' berdurasi 5:34 menit, menceritakan Riko ketika pulang sekolah merasa udara hari itu lebih panas dari biasanya. Dari jendela kamarnya Riko melihat matahari bersinar sangat terik dan jaraknya terlihat dekat. Lalu ia bertanya-tanya, mungkinkah jarak matahari dan bumi adalah penyebabnya sehingga udara sangat panas hari itu?

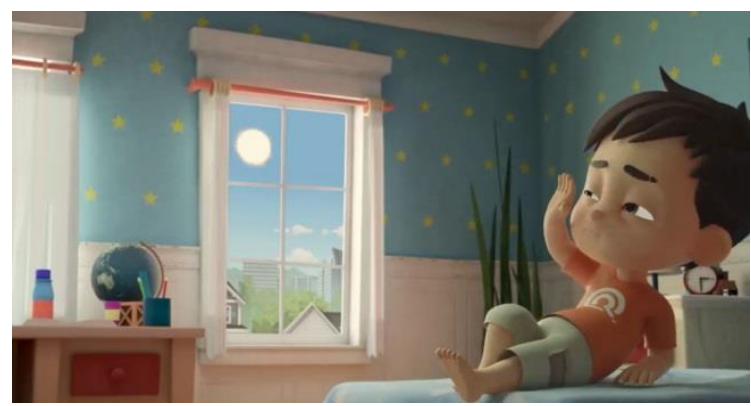

Gambar 4 : Riko merasa gerah dan silau Sumber: Riko the Series, Season 1, Episode 11, menit ke-00:00:58.

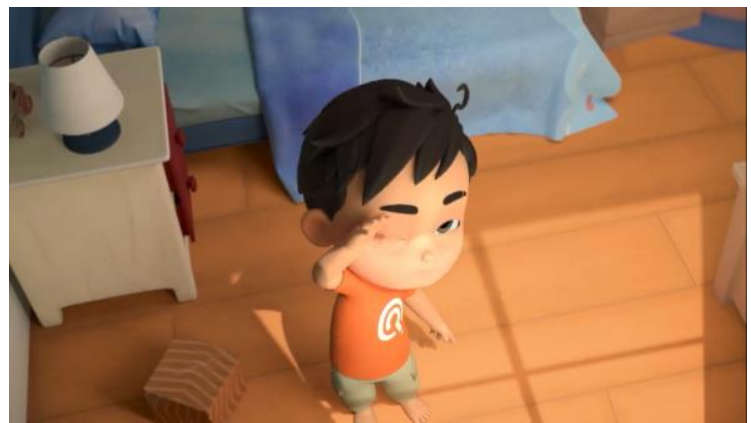

Gambar 5 : Riko melihat matahari bersinar terik lalu berinisiatif mengukur jarak antara matahari dan bumi

Sumber: Riko the Series, Season 1, Episode 11, menit ke-00:01:12.

Dalam kajian psikologi, pada adegan diatas (sequence kamar tidur, menit ke 00:00:57-00:01:14) sang tokoh utama (Riko) mengalami sebuah peristiwa perkembangan kognitif yang terjadi pada anak usia 7-12 tahun yaitu tahap konkrit operasional. Piaget merumuskan bahwa pribadi anak terbentuk melalui proses belajar yang melibatkan proses berfikir yang sangat kompleks dan merupakan peristiwa mental yang nantinya mendorong terjadinya sikap maupun perilaku. (Juwantara, 2019, h.2). 
Tahap perkembangan kognitif yang dialami Riko diatas jika diproyeksikan kedalam bagan triadik, akan menjadi semiosis pada tahap firstness sebagaimana gambar dibawah ini :

\section{Interpretant :}

Kesimpulan Riko bahwa penyebab udara panas adalah jarak matahari-bumi

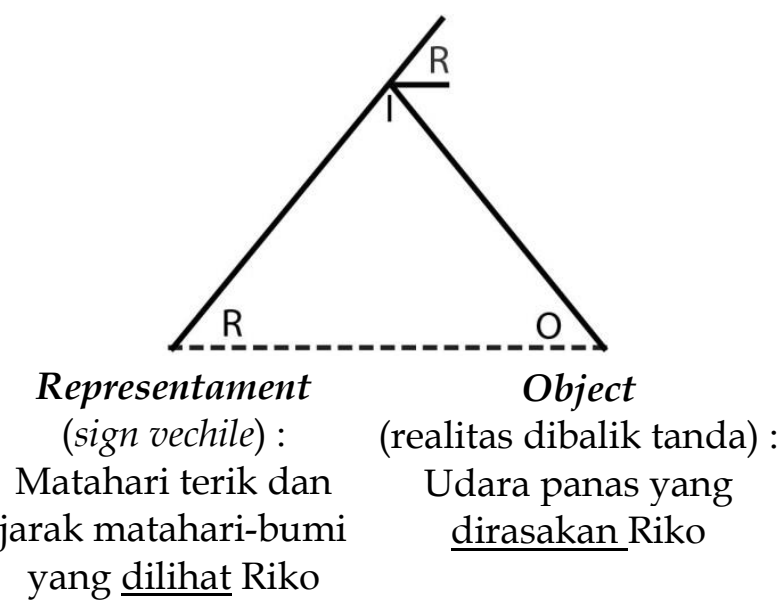

\section{Gambar 6 : Bagan semiosis firstness}

Pembacaan triadik dimulai dari arah kiri bawah dengan urutan representament $[\mathrm{R}]$ - object $[\mathrm{O}]$ - [I]. Semiosis diawali oleh representament $[R]$ sebagai representasi dari realitas yakni object [O]. 'Object' disini tidak diartikan sebagai benda konkrit, namun merujuk pada realitas yang terjadi dalam adegan film. Udara panas yang dirasakan Riko adalah realitas yang sedang dialami Riko, dilambangkan dengan [O]. Teriknya sinar matahari dan jarak antara matahari dan bumi yang tampak dekat hadir sebagai 'tanda konkrit' yang dilihat Riko, inilah yang disebut representament [R]. Riko mempersepsi kejadian tersebut dengan pengetahuanpengetahuan yang sudah ia miliki sebelumnya menjadi persepsi baru dalam sebuah kesimpulan. Ia menyimpulkan bahwa penyebab udara terasa sangat panas disebabkan oleh jarak bumi dan matahari yang begitu dekat. Persepsi ini adalah interpretant [I], tak lain adalah makna yang berhasil dibentuk kognisi Riko atas dasar hubungan kontinuitas antara representament dengan object.

Dari semiosis firstness diatas, kategori tanda-tanda hasil semiosis yang muncul dapat diidentifikasikan berdasarkan sifat relasinya antara representament dengan object. Jenis tanda berdasarkan relasinya sebagaimana ditulis Hoed (2014, h.9), dalam sequence kamar tidur Riko, scene 00:01:57- 00:00:14) yaitu :

1. Index adalah tanda dimana relasi object dan representament berdasarkan kausal dan kontinuitas.

2. Icon adalah relasi tanda yang representament dan object memiliki kemiripan identitas (secara visual).

3. Symbol adalah tanda yang makna representament nya berdasarkan konvensi sosial.

\section{Tabel 1 : Bagan hasil analisa semiotis tahap firstness.}

\begin{tabular}{|l|l|}
\hline Elemen Visual & $\begin{array}{l}\text { Kategori Tanda \& } \\
\text { Unsur Semiosis }\end{array}$ \\
\hline Gambar 4 & \begin{tabular}{l}
\multicolumn{1}{|c|}{$\underline{\text { Index }}$} \\
Udara panas yang \\
dirasakan Riko, \\
dipresentasikan \\
dalam scene matahari \\
yang bersinar terik. \\
Adegan tersebut \\
menampilkan \\
kausalitas dan terjadi \\
secara
\end{tabular} \\
\hline Gambar 5
\end{tabular}


JURNAL PUBLIPRENEUR: POLITEKNIK NEGERI MEDIA KREATIF

Vol. 8, No. 2, December 2020, hal. 31-44

Submitted: 1 December 2020

Revised: 10 December 2020

Accepted: 20 December 2020

\begin{tabular}{|c|c|}
\hline $\begin{array}{l}\text { Elemen } \\
\text { Visual }\end{array}$ & $\begin{array}{c}\text { Kategori Tanda \& } \\
\text { Unsur Semiosis }\end{array}$ \\
\hline \multirow{3}{*}{$\begin{array}{l}\text { Scene: } \\
\text { 00:00:57- } \\
\text { 00:01:14 } \\
\text { Riko merasa } \\
\text { gerah dan } \\
\text { silau oleh } \\
\text { teriknya } \\
\text { matahari. }\end{array}$} & $\begin{array}{l}\text { berkelanjutan } \\
\text { (kontinuitas). }\end{array}$ \\
\hline & $\begin{array}{l}\quad \underline{\underline{I c o n}} \\
\text { Udara panas dan } \\
\text { teriknya cahaya } \\
\text { matahari dalam logika } \\
\text { science, keduanya } \\
\text { memiliki wujud zat } \\
\text { yang berbeda. } \\
\text { Begitupun ketika } \\
\text { divisualkan dalam } \\
\text { film tidak terdapat } \\
\text { keserupaan identitas. } \\
\text { Maka scene ini tidak } \\
\text { memiliki tanda } \\
\text { dengan kategori icon } \\
\text { didalamnya. }\end{array}$ \\
\hline & $\begin{array}{l}\quad \underline{\text { Symbol }} \\
\text { Symbol yang } \\
\text { dimaksudkan disini } \\
\text { adalah makna yang } \\
\text { dicerap atau } \\
\text { disimpulkan Riko } \\
\text { bahwa penyebab } \\
\text { udara panas yaitu } \\
\text { jarak matahari -bumi. } \\
\text { Kesimpulan tersebut } \\
\text { terbentuk semata-mata } \\
\text { berdasarkan tingkat } \\
\text { pengetahuan dan } \\
\text { pengalaman Riko } \\
\text { sebagai anak berusia } 8 \\
\text { tahun. Tidak ada } \\
\text { unsur konvensi sosial } \\
\text { didalamnya. }\end{array}$ \\
\hline
\end{tabular}

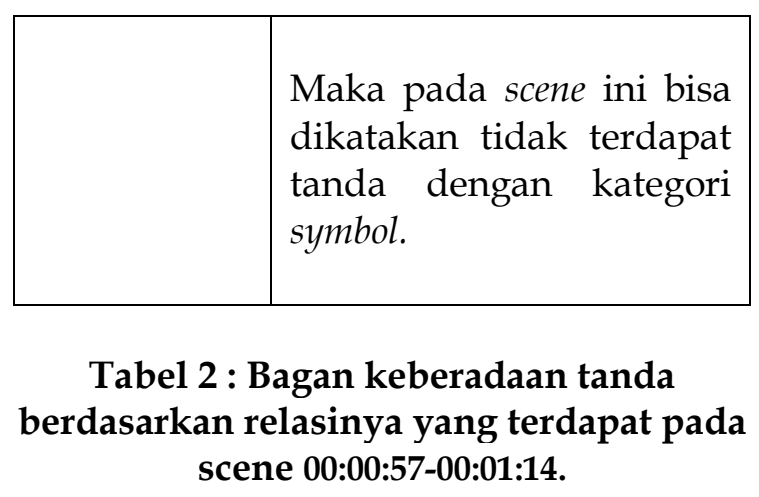

\begin{tabular}{|c|c|c|c|}
\hline Scene & Index & Icon & Symbol \\
\hline 00:00:57- & $\checkmark$ & - & - \\
00:01:14 & & & \\
\hline
\end{tabular}

Pada semiosis tahap firstness diatas, interpretasi Riko belum mendorongnya untuk melakukan sebuah tindakan atau representasi mental. Tindakan Riko akan muncul pada tahap semiosis secondness yang ditampilkan pada scene berikutnya didalam sequence yang sama.

Setelah melihat matahari bersinar terik dari balik jendela kamar (Gambar 4 dan 5, menit ke 00:00:57-00:01:14), Riko menginterpretasi bahwa penyebab udara panas adalah jarak mataharibumi. Dalam semiosis firstness, kesimpulan Riko tak lain adalah Interpretant [I]. Interpretant ini kemudian berubah menjadi Representament baru untuk semiosis tahap kedua (secondness).

Berikut adalah bagan semiosis secondness yang tampil pada menit ke 00:00:18 - 00:02:00. 


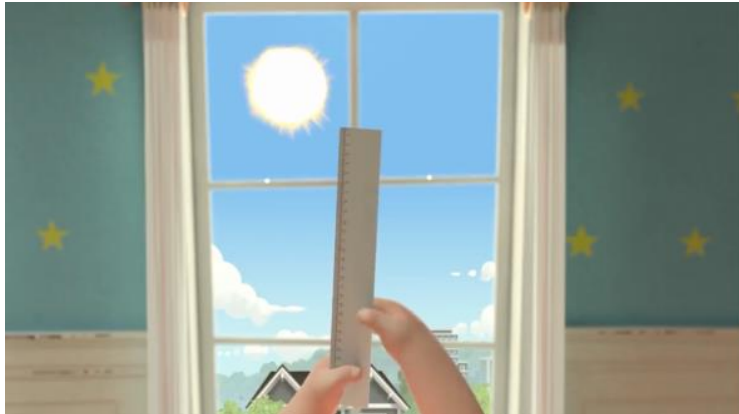

Gambar 6: Riko mengukur jarak matahari dan bumi dengan penggaris

Sumber: Riko the Series, Season 1, Episode 11, menit ke-00:01:21

\section{Interpretant}

Riko memutuskan untuk mengukur jarak matahari-bumi dari jendela kamar menggunakan penggaris.

Proyeksi jarak matahari-bumi yang dilihat Riko pada penggaris menunjukan $30 \mathrm{~cm}$.

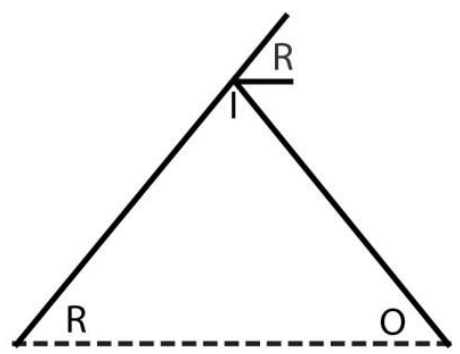

Representament :

Kesimpulan

(dalam kognisi)

Riko bahwa

penyebab udara

panas adalah

dekatnya jarak

matahari-bumi,

berubah menjadi

ide untuk

mengukur jarak

matahari bumi.

Gambar 7: Semiosis pada scene Riko mengukur jarak matahari-bumi

Semiosis secondness (tahap kedua) dimulai dari Representament [R]. Representament [R] berasal dari
Interpretant [I] pada semiosis firstness. Kesimpulan Riko bahwa penyebab udara panas adalah dekatnya jarak antara matahari dan bumi, membawa Riko pada sebagai sebuah ide untuk mengukur jarak matahari bumi. Ide tersebut merupakan hasil dari proses berpikir logis Riko ketika ia melihat sebuah fenomena alam dan mengalami kejadian tersebut secara langsung. Apa yang Riko simpulkan dan ide yang muncul dibenaknya dilatari oleh dorongan Riko untuk menemukan solusi dari udara panas yang ia rasakan. Untuk itu Riko berinisiatif untuk terlebih dahulu mencari penyebabnya. Keingintahuan Riko tersebut dapat disebut sebagai realitas, yaitu object [O] yang melatari munculnya representament [R].

Relasi antara realitas (object) yang melatari munculnya ide Riko (representament), membangun sebuah makna dalam kognisi Riko setelah ia mencerap 'tanda visual' (lihat gambar 4 dan 5). Yaitu pemandangan di hari yang panas disertai matahari yang bersinar terik yang Riko lihat dari balik jendela kamar. Yang membedakan tahap semiosis secondness dengan firstness, representament keluar dalam bentuk sebuah gagasan, bukan sekedar tanda konkrit yang dapat diindera. Maka ketika relasi dengan object dengan respresentament terjadi, interpretasi [I] dalam kognisi Riko terbentuk sebagai representasi mental dalam bentuk tindakan. Riko memutuskan untuk mengukur jarak antara matahari dan bumi dari jendela kamarnya menggunakan penggaris. Proyeksi jarak matahari-bumi yang dilihat Riko pada penggaris menunjukan angka $30 \mathrm{~cm}$ (gambar 6). Riko sebagai anak berusia 
JURNAL PUBLIPRENEUR: POLITEKNIK NEGERI MEDIA KREATIF

Vol. 8, No. 2, December 2020, hal. 31-44

Submitted: 1 December 2020

Revised: 10 December 2020

Accepted: 20 December 2020

tahun menganalogikan angka tersebut adalah jarak konkrit antara matahari dan bumi. Sampai tahap ini, kategori tanda berdasarkan relasi representament, object dan interpretant yang muncul dalam menit ke 00:00:18 - 00:02:00 dapat diidentifikasu sebagai berikut :

Tabel 3 : Bagan hasil analisa semiotis tahap secondness.

\begin{tabular}{|c|c|}
\hline Elemen Visual & $\begin{array}{c}\text { Kategori Tanda \& } \\
\text { Unsur Semiosis }\end{array}$ \\
\hline $\begin{array}{l}\text { Gambar } 6 \\
\text { Sequence : } 02 \\
\text { Kamar tidur } \\
\text { Riko } \\
\text { Scene : } \\
00: 00: 18 \text { - } \\
\text { 00:02:00 } \\
\text { Riko } \\
\text { mengukur } \\
\text { jarak antara } \\
\text { matahari- bumi } \\
\text { menggunakan } \\
\text { penggaris. }\end{array}$ & $\begin{array}{l}\quad \underline{I n d e x} \\
\text { Proyeksi jarak } \\
\text { matahari - bumi pada } \\
\text { penggaris sepanjang } \\
30 \mathrm{~cm} \text { meskipun } \\
\text { bukan sebuah fakta } \\
\text { yang benar, namun } \\
\text { bagi kemampuan } \\
\text { logika Riko hal } \\
\text { tersebut menunjukan } \\
\text { sebuah kemiripan } \\
\text { yang 'menunjukan' , } \\
\text { atau bisa juga disebut } \\
\text { sebagai 'miniatur' } \\
\text { dari jarak matahari - } \\
\text { bumi yang } \\
\text { sebenarnya. } \\
\text { Diperkuat dengan } \\
\text { narasi Riko : } \\
\text { “Pantesan panas } \\
\text { banget, cuma } 30 \mathrm{~cm} . ”\end{array}$ \\
\hline & $\begin{array}{l}\qquad \frac{\text { Icon }}{\text { Dari tanda visual }} \\
\text { yang ditampilkan } \\
\text { tidak terdapat } \\
\text { keserupaan identitas } \\
\text { baik dari matahari, } \\
\text { penggaris, maupun } \\
\text { dialog yang } \\
\text { diucapkan Riko tidak }\end{array}$ \\
\hline
\end{tabular}

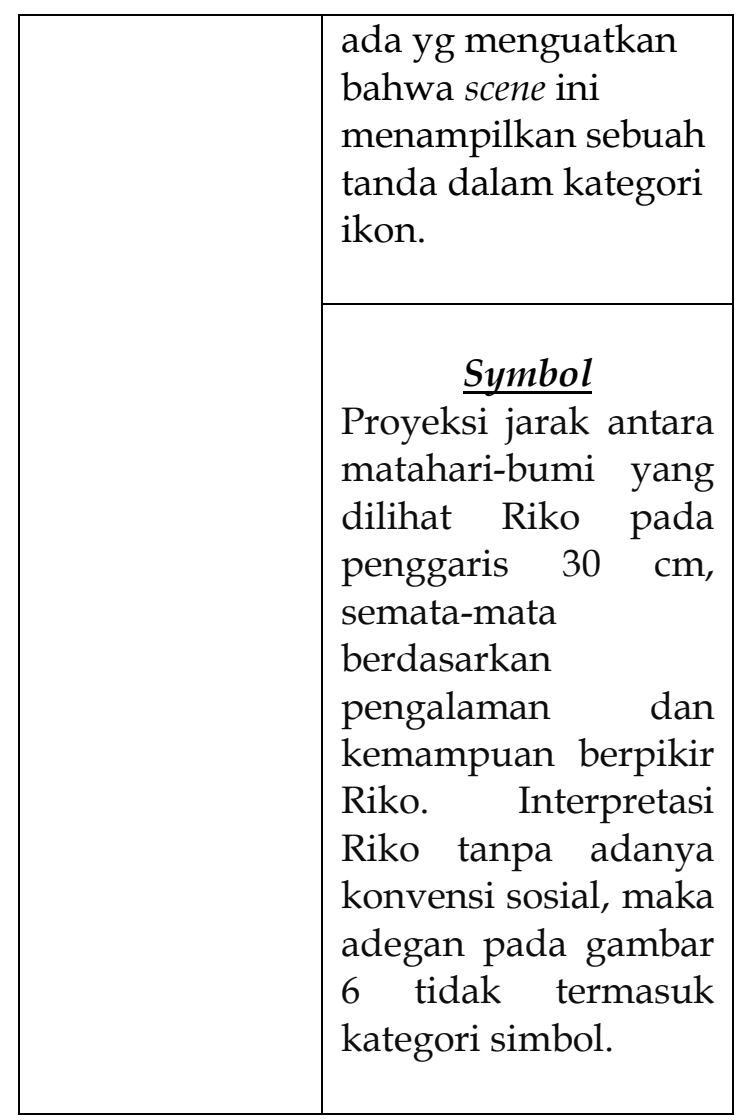

Tabel 4 : Bagan keberadaan tanda berdasarkan relasinya yang terdapat pada scene 00:00:18 - 00:02:00.

\begin{tabular}{|l|c|c|c|}
\hline \multicolumn{1}{|c|}{ Scene } & Index & Icon & Symbol \\
\hline 00:00:18 & $\checkmark$ & - & - \\
- & & & \\
00:02:00 & & & \\
\hline
\end{tabular}

Sampai pada semiosis secondness, setelahnya semiosis tahap ketiga akan terjadi dan terus berlangsung berulangulang. Pada dasarnya proses pemaknaan tanda-tanda tidak terbatas seiring dengan dinamika yang melingkupinya. Begitu pula semiosis yang terjadi pada kognisi Riko, akan terus terjadi dan berulang-ulang seiring stimulus-stimulus yang ia terima dari lingkungan sekitar. Studi semiosis firstness dan secondness dari scene yang ditampilkan berturut-turut diatas, 
memperlihatkan relasi unsur-unsur semiotik tersebut berproses pada perkembangan berpikir Riko dengan tahapan yang persis sama dengan teori perkembangan kognitif anak berusia 8 tahun. Berikut adalah ilustrasi bahwa semiosis dalam kognisi Riko yang ditampilkan melalui adegan-adegan yang dibangun dari bahasa visual dan verbal, sudah sesuai dengan teori psikologi perkembangan anak.

Bagan 1 : Kesesuaian teori semiotika dengan psikologi perkembangan anak

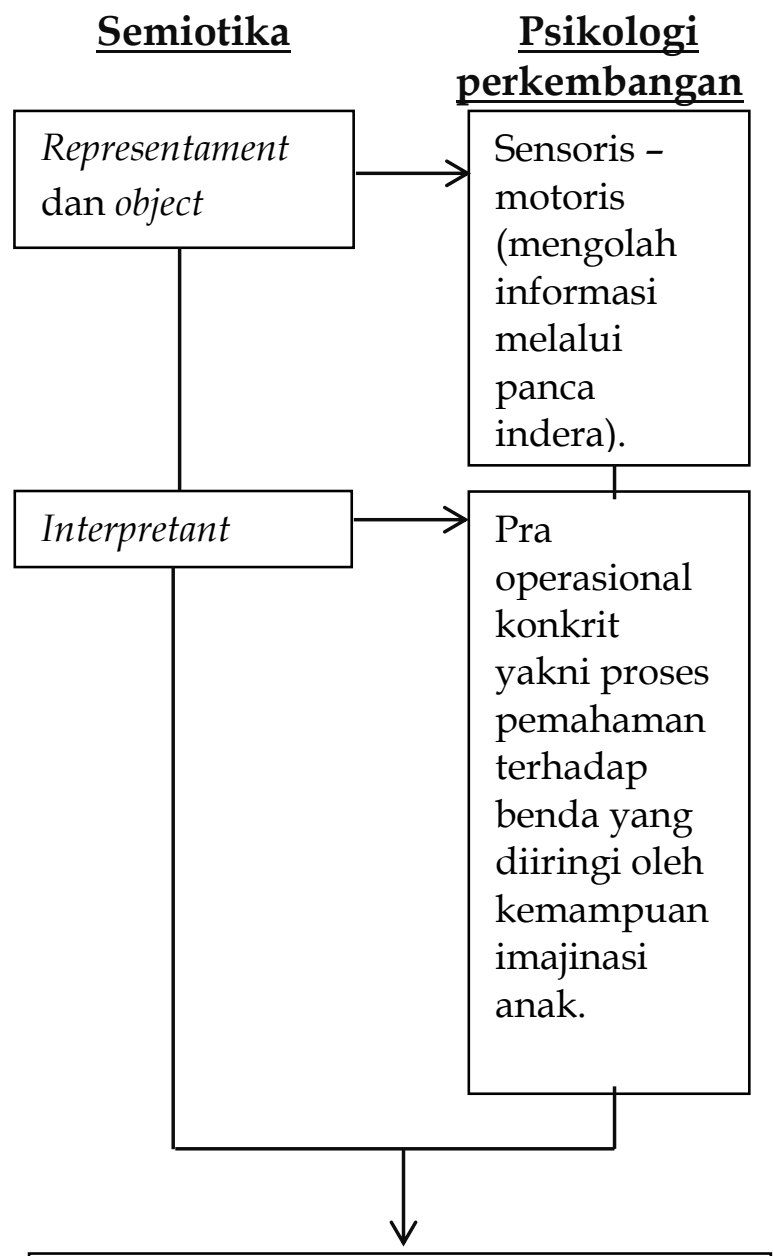

Perkembangan psikis : kemampuan anak dalam berbahasa, kemampuan emosional, berinteraksi dengan lingkungan, pemahaman moral dalam membedakan baik dan buruk, memahami konsep agama.

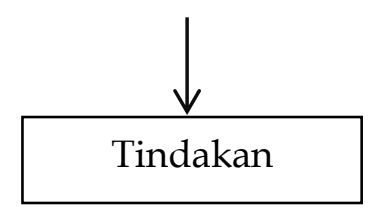

Dari analisis dua scene dengan total durasi 1 menit 3 detik diatas, sudah sedemikian banyak terjadi proses pemaknaan tanda-tanda visual yang berimpilikasi pada perkembangan psikologis pra operasional konkrit Riko. Jika dianalisis semua scene pada film 'Riko : Jarak Matahari dan Bumi', akan lebih banyak temuan yang menarik yang menyadarkan kita akan besarnya pengaruh 'pemaknaan tanda' terhadap perkembangan psikologi anak. Diluar kajian semiotika yang prosesnya terus menerus tanpa batas, asimilasi juga salah satu aspek yang berperan dalam pembentukan persepsi, pola pikir dan tindakan seseorang. Asimilasi adalah penyatuan (pengintegrasian) informasi, persepsi, konsep dan pengalaman baru kedalam yang sudah ada dalam benak seseorang (Sanjaya, 2010:132). Begitupun dengan interpretasi Riko bahwa penyebab udara panas adalah jarak antara matahari-bumi, lalu selanjutnya Riko terdorong melakukan sebuah tindakan dengan mengukur menggunakan penggaris - tentu dipengaruhi asimilasi pengetahuan dari pengalaman-pengalaman Riko sebelumnya. Riko menggunakan kemampuan yang sudah ada untuk menghadapi masalah yang dihadapinya dalam lingkungannya.

Pada scene selanjutnya, penulis menganalisa plot cerita tanpa mendeskripsikan alur semiosisnya. 


\section{JURNAL PUBLIPRENEUR: POLITEKNIK NEGERI MEDIA KREATIF Vol. 8, No. 2, December 2020, hal. 31-44}

Submitted: 1 December 2020

Revised: 10 December 2020

Accepted: 20 December 2020

Pernyataan Riko tentang jarak matahari dan bumi sejauh $30 \mathrm{~cm}$ disanggah Robot Q110. Robot Q110 adalah sebuah pengkarakteran dengan gaya personifikasi, berperan sebagai sahabat Riko yang selalu bisa menjelaskan fenomena-fenomena alam yang dilihat Riko secara ilmiah. Jarak matahari dan bumi sejauh 149,6 juta kilometer dijelaskan secara ilmiah melalui adeganRobot Q110 mengajak Riko pergi keluar angkasa. Ia memproyeksikan jarak antara matahari dan bumi melalui sistem tata surya yang menunjukan perbandingan ukuran matahari dengan planet-planet termasuk bumi.

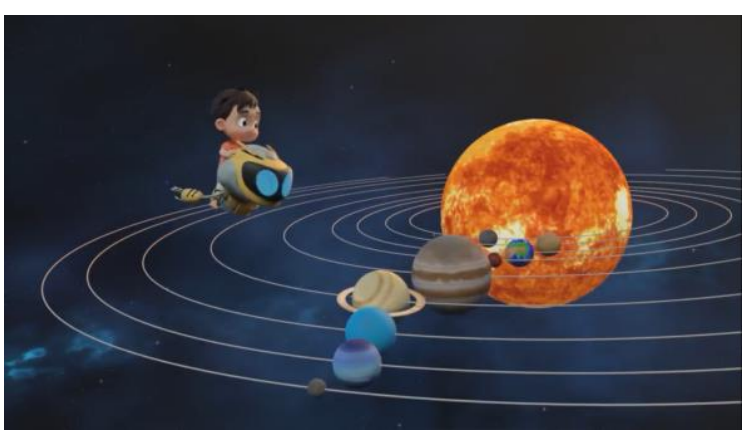

Gambar 7 : Robot Q110 memberikan penjelasan konkrit melalui dialog dan visual mengenai jarak antara matahari dan bumi

Sumber: Riko the Series, Season 1, Episode 11, menit ke-02:18

Penjelasan konkrit dengan visualisasi tata surya seperti gambar diatas sangat efektif untuk menyampaikan informasi kepada anak-anak. Setelahnya, diperkenalkan Al-Batani, pakar astronomi muslim pertama yang berhasil mengukur jarak bumi dan matahari, rotasi bumi terhadap matahari serta bumi yang berputar pada porosnya jauh sebelum Galileo Galilei.

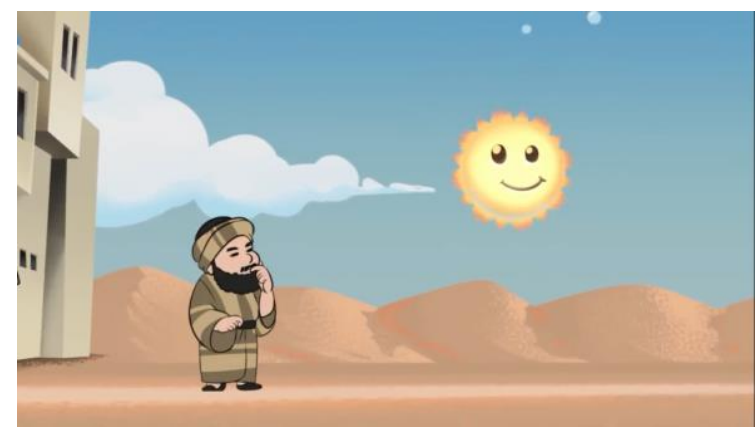

Gambar 8: Al-Batani, astronom muslim pertama yang mengungkap jarak antara bumi dan matahari

Sumber: Riko the Series, Season 1, Episode 11, menit ke-03:05

Pada akhir cerita, disampaikan sebuah ayat dalam Al-Qur'an tentang penciptaan langit dan bumi, siang dan malam serta siklus tata surya.

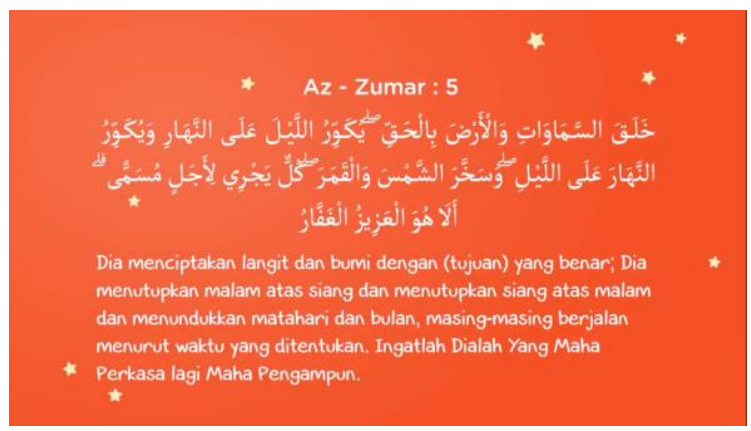

Gambar 9: Surat Az-Zumar ayat 5 Sumber: Riko the Series, Season 1, Episode 11, menit ke-03:50

Dengan total durasi 05:34 menit, subjeksubjek yang disampaikan pada 'Riko : Jarak Matahari dan Bumi 'cukup kompleks karena terdiri dari beberapa subjek yang berbeda yaitu ilmu pengetahuan, sejarah lalu dihubungkan berdasarkan petunjuk Al-Qur'an. Melalui metode semiotika pragmatis yang digagas Peirce lalu dihubungkan dengan teori psikologi perkembangan anak, menunjukan bahwa unsur-unsur semiotis yang disajikan dalam 'Riko: 
Jarak Matahari dan Bumi' sangat sesuai dengan kaidah-kaidah psikologi perkembangan anak. Sehingga cerita dapat dituturkan dengan sederhana, mudah dipahami, dan menghibur melalui bahasa verbal dan bahasa visual yang disesuaikan dengan kemampuan logika dan emosional anak-anak.

\section{KESIMPULAN}

Menjawab rumusan masalah dan tujuan penelitian yang dikemukakan pada Pendahuluan, hasil analisis menunjukan bahwa unsur-unsur semiotis yang disajikan dalam 'Riko: Jarak Matahari dan Bumi' sudah sangat sesuai dengan kaidah-kaidah psikologi perkembangan anak.

Dari dua scene dengan total durasi 1 menit 3 detik, sudah sedemikian banyak terjadi proses pemaknaan tanda-tanda visual yang berimpilikasi pada perkembangan psikologis pra operasional konkrit Riko. Jika dianalisis semua scene pada film 'Riko : Jarak Matahari dan Bumi', akan lebih banyak temuan yang mengingatkan kita pada betapa pentingnya untuk menyajikan konten-konten positif pada berbagai media yang dikonsumsi masyarakat luas, terutama anak-anak. Stimulusstimulus (tanda-tanda visual) dicerap dan dipahami sebagai kemampuan anak dalam berbahasa, kemampuan emosional, berinteraksi dengan lingkungan, pemahaman moral dalam membedakan baik dan buruk, bahkan memahami konsep agama. Pada akhirnya, semua kemampuan anak tersebut akan terepresentasi kedalam bentuk tindakan. Baik buruknya tindakan, tentunya dipengaruhi oleh sifat stimulus-stimulus yang diterima sebelumnya. Disamping itu pola pikir dan tindakan seseorang dipengaruhi oleh asimilasi sebagaimana dituturkan Sanjaya, yaitu penyatuan (pengintegrasian) informasi, persepsi, konsep dan pengalaman baru kedalam yang sudah ada dalam benak seseorang (2010:132).

Pernyataan diatas, memperjelas bahwa 'tanda-tanda' yang ditafsirkan, lalu terepresentasi sebagai pola pikir dan tindakan adalah proses terus menerus tanpa batas seperti halnya semiosis. Jika 'tanda-tanda' yang disampaikan melalui media secara terus-menerus dalam jangka waktu yang lama bersifat posistif, maka akan terbentuk persepsi, pola pikir dan prilaku positif. Begitupun sebaliknya, jika 'tanda-tanda' bersifat negatif maka dampaknya pun akan negatif. Bisa dibayangkan terkikisnya moralitas masyarakat, terlebih anakanak jika kesehariannya diberikan tontonan yang tidak edukatif.

Ketika anak sudah mampu menggunakan konsep berpikir (kognitif) sesuai usianya, maka tugas para pendidik (orang tua dan lingkungan sekitar) mengembangkan metode pengajaran. Terlebih, dalam ranah penelitian ini, 'pendidik' yang dimaksudkan adalah para pelaku media, sineas, penulis, dan segenap masyarakat yang berhubungan dengan media pembuatan edukasi digital baik dalam bentuk film, games, musik dan lainnya.

Riko the Series adalah salah satu contoh media hiburan anak-anak yang sangat edukatif dan inspiratif. Kompleksitas subjek pembelajaran dapat dituturkan dengan sedemikian menarik dan mudah dipahami anak-anak. Dengan 


\section{JURNAL PUBLIPRENEUR: POLITEKNIK NEGERI MEDIA KREATIF Vol. 8, No. 2, December 2020, hal. 31-44}

format hiburan film yang mudah diakses kapanpun dan dimanapun, diharapkan media-media edukasi karya para sineas Indonesia dengan pesanpesan positif seperti Riko the Series akan semakin banyak. Mengingat film adalah entitas budaya (material culture) dari dan untuk dimana masyarakat tersebut berada serta fungsi film sebagai wadah informasi dan edukasi yang mampu mencakup konteks yang luas dengan dampak massif.

\section{DAFTAR PUSTAKA}

Tesis

Aisyah, Lani Siti Noor. (2018). Representasi Identitas Budaya Sunda pada Perkakas Memasak dan Perangkat Makan Tradisional Berbahan Bambu (Studi Kasus Desa Linggajaya di Kabupaten Sumedang Provinsi Jawa Barat). Jakarta. Universitas Trisakti.

Buku

Eriyanto. (2013). Analisis Naratif: Dasardasar dan Penerapannya dalam Analisis Teks Berita Media. Jakarta. Prenadamedia Group.

Hoed, Benny. H. (2014) Semiotik E Dinamika Sosial Budaya. Depok. Komunitas Bambu.

Okke Kusuma Sumantri Zaimar. 2016. Krisis Kebudayaan Indonesia Masa Kini. Dalam Sarumpaet, Riris. K . Toha (Ed), Krisis Budaya ? Oasis Guru Besar Fakultas Ilmu Pengetahuan Budaya UI (hh 131148. Jakarta : Yayasan Pustaka Obor.

Masganti, Sit. (2015). Psikologi Perkembangan Anak Usia Dini. Jakarta. Prenadamedia Group.
Sobur, Alex. (2016). Semiotika Komunikasi. Bandung. PT. Remaja Rosdakarya.

Saidi, Acep Iwan. (2017). Desain, Media dan Kebudayaan. Bandung. Penerbit ITB.

Jurnal

Juwantara, Ridho Agung. (2019). Analisis Teori Perkembangan Kognitif Piaget pada Tahap Anak usia Operasional Konkret 7-12 Tahun dalam Pembelajaran Matematika. Yogyakarta. Pascasarjana Universitas Islam Negeri Sunan Kalijaga.

https://core.ac.uk/download/pdf /327227393.pdf

Piliang, Yasraf Amir. (2019). Semiotika Teks : Sebuah Pendekatan Analisis Teks. MediaTor : Jurnal Komunikasi Unisba, 5(2), 189-198.

https://ejournal.unisba.ac.id/index .php/mediator/article/view/1156/ $\underline{715}$

Sanjaya, Wina. (2010).Strategi Pembelajaran Berorietnasi Standar Proses Pendidikan.Jakarta.Prenada Media Group.

Sya'dian, Triadi. 2015. Analisis Semiotika pada Film Laskar Pelangi. Proporsi : Jurnal Desain ,Multimedia, dan Industri Kreatif, 1(1), 51-63. http:/ / e-journal.potensiutama.ac.id/ojs/index.php/PROP ORSI/article/view/497/608

Film

Riko the Series - Jarak Matahari Bumi. https://www.youtube.com/chann el/UCHzkGRP2y- 
3QJQWzVkHNGgg, diakses pada 7 September 2020.

Riko

the

Series.

https://www.garissepuluh.com/ri

ko-the-series/, diakses pada 10

September 2020. 